\title{
Examination of the Relationship between Certain Gene Variations and Psychological Factors with Physical Activity Level in the Individuals with the Diagnosis of Schizophrenia and Bipolar Disorders
}

\author{
Hatice Toy ${ }^{1}$, Erkut Tutkun ${ }^{1}$, Ümit Zeybek ${ }^{2}$, Itır Tarı Cömert ${ }^{3}$, İbrahim Taymur ${ }^{4}$ \\ ${ }^{1}$ Uludag University, Faculty of Sports Sciences, Bursa/Turkey \\ ${ }^{2}$ Istanbul University, Aziz Sancar Experimental Medicine Research Institute, Department of Molecular Medicine, \\ Istanbul/Turkey \\ ${ }^{3}$ Fatih Sultan Mehmet Vakıf University, Department of Psychology, Istanbul/Turkey \\ ${ }^{4}$ Health Sciences University, Bursa High Specialist Training and Research Hospital, Bursa/Turkey \\ Correspondence: Erkut Tutkun, Uludag University, Faculty of Sports Sciences, Bursa/Turkey.
}

Received: February 18, 2019

Accepted: March 5, 2019 Online Published: March 11, 2019

doi:10.11114/jets.v7i4.4072

URL: https://doi.org/10.11114/jets.v7i4.4072

\begin{abstract}
The research aims to examine certain gene variations and to examine relationship between psychological factors and activity levels by the individuals with schizophrenia and bipolar diagnosis. This research has been conducted with the participation of the patients with schizophrenia and bipolar diagnosis in the Mental Facility of Bursa Dört Çelik at the University of Health Science and all the patients take part in physical exercise activities regularly. During the research, IPAQ has been applied to determine participants' physical activity levels whereas Beck's Depression Inventory, Beck's Anxiety Inventory, Sta1 Form TX-I-II, Beck's Hopelessness Index has been applied to determine their psychological status after socio-demographic information of participants was obtained by demographic form. In order to examine properties of the participants genetically, oral swabs were obtained by SWAP kite. Genetic variations of cases have been recurred as a result of genotyping analysis of MAO-A, COMT, TH and SLC6A4 genes in GenoFeel panel by using isolated DNAs yielded from swap samples. When the results obtained from statistical analysis are analyzed, it has been seen that genetic properties pair with psychological factor meanwhile the characteristics of diseases bear a resemblance to these measurement. It was determined in this research that, genetic factor were matched with psychological factors, these measurement results resembled with the characteristic of diagnosed ailments as well and schizophrenia and bipolar patients have significance in MAO-A and COMT figures, excessive activation of TH (tyrosine hydroxylase) enzyme may also be included in excessive dopamine production, Homozygote mutation and heterozygote genotypes of gene which is related to SLC6A has rational increase whereas no significance was observed in schizophrenia patient's group. As a consequence it shouldn't be neglected that exercising should be a part of schizophrenia and bipolar patients' life, that exercise, genetic parameters and psychological tests have positive contributions for treatments and that medical treatment has positive contributions with exercise.
\end{abstract}

Keywords: mental disorder, mood disorder, exercise, genetics factors, psychology, chronic psychiatric disorders

\section{Introduction}

Physical activity and exercise definitions have increasing important part in our daily life in accordance with inactivity which comes out with today's life conditions of our World. Physical activity is a definition which involves the whole bodily movement that lead to energy expenditure whereas; exercise is more explicit definition which contains whole planned and remitting movements which are configured to protect physical health, to ameliorate and improve our health. Many studies have showed the positive effects of exercises to prevent chronic ailments and the course of diseases (Anding et al., 2015).

Schizophrenia is a chronicle and severe psychological disease which causes to importance instability in emotions, judgment, behavior and perception of individual's and which influences individuals and those around patient significantly. While this disease causes to high loss in personal productivity and competence with general functionality, it also becomes an important psychological problem in accordance with short lifetime and high self-destruction incidence. According to another definition; schizophrenia is an indisposition in which psychotic symptoms and 
dysfunction of social functions are emerged. It is also stated that schizophrenia is a community health care problem which causes to collapse in individual's state of mind and competence and which is frequently emanated in earlier ages and which has different progression and outcome however, schizophrenia's etiology hasn't still known entirely nowadays. In addition schizophrenia emanates in younger ages and it influences $1 \%$ of the society. According to World Health Organization data, it is stated that schizophrenia is one of the ten most important ailments which cause to competence collapse of patients (Buchanan \& Carpenter 2005; Ertuğrul 2005; Soygür et al., 2007; Atmaca \& Durat 2016).

On the other hand, is a complex and remitting bipolar disorder which is progressed with depression, mania or both of them at the same time. Patients return to normal mood between these remitting attacks. According to another definition bipolar disorder is a chronic mental disease which is progressed with remitting periodical or cyclic depression, mania or hypomania attacks, which influences psycho-social status and functions of patients significantly. The most known characteristic of bipolar disorder is emotional fluctuations in mood and individuals are generally characterized with mood disorders due to its effects on emotions. Since the moods of the individuals differ from two extremities that contain exuberance, outburst or depression, is also name as "disorders with two extremities". It generally varies between $0.45 \%$ and $5.5 \%$ lifelong and it changes intersocietally but its prevalence is generally about $2 \%$, bipolar disease is chronic and severe mental disorder which has $0.6 \%$ prevalence for BD-I and $0.4 \%$ prevalence for BD-II by differing according to cultures and ethnical groups. BD is in the sixth place among mental disorder and it has $20^{\text {th }}$ place among the whole ailments in the World. According to general population, BD patients have a life expectancy less than 10 years (Ugur 2008; Isik et al., 2008; Koroglu 2013; Stubbs et al., 2016; Vancampfort \& Goldstein 2018).

Monoamine oxidase enzyme is a key enzyme which is located on mitochondrial membrane and monoamines metabolism. These enzymes are coded by neighborhood gene locations. Various polymorphisms in MAO-A genes are identified with behavioral disorders and they were examined deeply (Sabol et al. 1998). Catechol-O-Methyl-Tranferase is localized in 22q11.2 with COMT gene. COMT metabolizes many catecholamine molecules like; dopamine, noradrenaline and adrenaline. Rs4680 is most studied single nucleotide polymorphism (SNP) in COMT gene which is also known as Val158Met. Methionine (Met) which is situated in $158^{\text {th }}$ position on COMT enzyme of this polymorphism leads to transformation of its amino acid to one valine (Val) amino acid (Bobb et al., 2006).

Tyrosine Hydroxylase (TH) gene has role in preparation of tyrosine hydroxylase that is important for normal working of nerve system and it is in the first step of the way of certain hormones which is called catecholamines. This enzyme also helps to transformation of protein ward (amino acid) to a catecholamine which is called tyrosine dopamine. Dopamine is also known as one of neurotransmitters and it transfers the signals among brain nerve cells to help the control of physical and emotional behaviors. Other catecholamines called norepinephrine and epinephrine are produced by dopamine and it is situated in autonomic nervous system which controls reflex body processes like regulating of blood pressure and regulating of body temperature (Yeung et al., 2011).

SLC6A4 gene is localized in 17q11.2. The most important functional polymorphism is situated in gene promoter zone (5-HTT gene-linked polymorphic region, 5-HTTLPR). $44 \mathrm{bp}$ has short (S) and long (L) alleles according to deletion/insertion state of tandem repeat (Heils et al., 1996). Short form of this gene called S allele utilization speed of serotonin related to transcriptional activity of carrier gene whereas long form of this gene called L allele is counterproductive (Collier et al., 1996).

Nowadays, gene and environmental interaction have more importance for psychiatric diseases' etiology however, psycho-social factors which are admitted as one of the reasons of the disease were neglected by certain dominant psychiatric views and as a result, gene-environment model accounts for more objective view (Baskak et al., 2009).

It's known that genetic factors include direct relations with various compounds like endurance, force, strength, speed, muscle fibrils compositions which are important for sportive performance, muscle structure and emotional mood. In other words, the interaction of genetic units like race, gender, genetic makeup, intelligence, loco-motor, neuromuscular and anatomical structure and psychological status each of which are one of the building stone of biological donation will be determinant of future performance and general state of health (Epstein 2003).

The relationship between exercises, genetic and psychological factors are frequently defined in related literature, therefore this study which aims to examine the physical activity levels of patients with schizophrenia and bipolar diagnosis, is the first study with multidisciplinary approach about this subject and this circumstance intensify authenticity of our study. We think that the research results obtained with this study will bring a new perspective in this domain.

\section{Method}

35 individuals who have schizophrenia and bipolar diagnosis have taken part in this research as 24 male and 11 female patients. Research has been conducted in four steps. The steps include; determination of demographical data, psychological measurements, analysis of physical activity level and genetic variations. 


\subsection{Subjects}

This research has been conducted with 24 male and 11 female patients with total 35 individuals who have schizophrenia and bipolar diagnosis and who joins physical exercise activities in Dört Çelik Mental Facility of Health Science University of Bursa. According to Helsinki Declaration, all of the participants were informed and each of the participants signed an approval form. Research has been certified by Clinical Investigation Ethics Committee of Bursa Uludag University (16th of October 2018 2018-17/14).

\subsection{Research Protocol and Design}

(a) Determination of demographical data (gender, age, marital status, profession, income status, home, family integrity etc.)

(b) Psychological measurements: the effects of patients' reaction levels on their sportive performances were determined with Beck's Anxiety Scale with 21 questions, Beck's Depression Inventory with 21 questions, Beck's Hopelessness Scale with 20 questions and STAI FORM TX-I-II with 40 questions (state-trait anxiety inventory) and evaluations of psychology team were associated with other data.

- Beck's Anxiety Scale: It was developed by Beck et al. (1988). This scale aims to determine frequency and severity of anxiety symptoms of the individuals. The scale contains 21 questions and the maximum point is 63 . Turkish availability and credibility studies were conducted by Ulusoy et al. (1998) and they defined this study's Cronbach Alpha internal consistency as 0.93.

- Beck's Depression Scale: It was developed by Beck et al. (1988) and Turkish availability and credibility studies were conducted by Avsar (2007). The aim of this scale isn't get a diagnosis of depression but it aims to determine the degree of depression with numerical values. Internal credibility of Beck's Depression Scale was tested between 0.73-0.92 with average 0.86 values (Avsar 2007).

- Beck's Hopelessness Scale: It was developed by Beck et al. (1974) and it aims to determine individuals' pessimism levels about future with 20 statements which contain emotions and opinions of the individuals for future. The statements of the scale were analyzed in emotional, motivational and cognitive sub-dimensions. The points of the scales vary from 0 to 20 . The higher points taken mean, the higher pessimism of the individual. Turkish availability and credibility studies were conducted by Seber et al. (1993) and this study's Cronbach Alpha internal consistency was defined as 0.82 .

- Stal Form TX-I-II: It was developed by Spielberger \& Gorsuch (1970) and it contains 40 questions which include quad test as State Anxiety Scale (STAI TX-I), Trait Anxiety Scale (STAI TX-II). Turkish availability and credibility studies were conducted by Oner \& Compte (1983) with secondary school students, high school students, Hacettepe University-Psychology Faculty Students and the parents thereof and Compte has also conducted a research in Holland with 1534 Turkish employees and their families with adolescent and adult participants and 200 physical and psychiatric patients. Cronbach Alpha internal consistency was defined as .94 and .96 for State Anxiety Scale (STAI TX-I) respectively and as .83 and .87 for Trait Anxiety Scale (STAI TX-II) respectively.

(c) Physical Activity Level:

- Determination of anthropometric prior conditions: age, length, anatomical prosperities.

- Body mass index of participant: It was obtained by Tanita TBF 200 (Japan) body fat analyzer.

- IPAQ scale was used to measure physical activity level of participant. Physical activity levels were evaluated by using Turkish version of International Physical Survey (IPAQ-SF) (Saglam et al. 2010). IPAQ-SF contains seven questions and it provides data about time spending for physical activity. It demanded from the participant to remember how often they join the physical activity for each activity during last seven days (frequency) and how long do they do each exercise (duration). Data obtained by IPAQ-SF was used to assume total duration of the physical activities for each day and other data were collected for each question (severe, median and walking). The research which was conducted with schizophrenia patients has shown that IPAQ is a current and credible inventory to evaluate physical activity level in the population (Faulkner et al. 2006).

(d) Genetic Variation Analysis: First of all the literature was scanned and the sets of primer-prob was designed so that a couple of primitive genome is reproduced for each SNP which targets SNPs on the genes determined as effective on psychological factor diathesis and besides, it was also designed so that it would produce 1 pro-primer or pre-primes to meet primer design conditions and demands of mutated targets for each SNP. Candidate SNP Genotyping Protocol which may have relation with psychological factors was used in the DNA isolation of obtained swab samples. The optimization of all studied sample types was continues with DNAs so that DNA concentration has reached to above $\mathrm{mg} / \mu \mathrm{l}$ and their measurement in OD 260/280 nm have reached between 1.6 and 2.0 routinely. In addition DNAs have 
become visible and their size control and intensity were provided with Agarose-gel electrophoresis by imposing DNAs to agarose-gel electrophoresis as a matrix. DNAs with desired amount and desired density were conserved at $-20 \mathrm{C}^{\circ}$.

\subsection{Statistical Analysis}

Data were analyzed by using the IBM SPSS Statistics version 20 software for Windows (IBM Corp., 2011, Armonk, NY, USA). Descriptive statistics were presented as mean and standard deviation. Significance level was ranked as $\mathrm{p}<0.05$.

\section{Results}

Measurement results of the researches are presented respectively.

Table I. Socio-demographic Characteristics of the Participants

\begin{tabular}{|c|c|c|c|c|}
\hline Variables & & $n$ & $\%$ & $\overline{\mathbf{x}} \pm \mathbf{s d}$ \\
\hline Genders & $\begin{array}{l}\text { Female } \\
\text { Male }\end{array}$ & $\begin{array}{l}11 \\
24\end{array}$ & $\begin{array}{l}31,4 \\
68,6\end{array}$ & $1,68 \pm 0,47$ \\
\hline Age & $\begin{array}{l}18-25 \\
26-33 \\
34-41 \\
42+ \\
\end{array}$ & $\begin{array}{c}6 \\
12 \\
10 \\
7 \\
\end{array}$ & $\begin{array}{l}17,1 \\
34,3 \\
28,6 \\
20,0 \\
\end{array}$ & $35,05 \pm 10,4$ \\
\hline Marital Status & $\begin{array}{l}\text { Married } \\
\text { Single } \\
\text { Widow } \\
\end{array}$ & $\begin{array}{c}8 \\
26 \\
1 \\
\end{array}$ & $\begin{array}{c}22,9 \\
74,3 \\
2,9 \\
\end{array}$ & $1,8 \pm 0,47$ \\
\hline Educational Status & $\begin{array}{l}\text { Illiterate } \\
\text { Primary Education } \\
\text { High school } \\
\text { Associate/Bachelor }\end{array}$ & $\begin{array}{c}1 \\
16 \\
14 \\
4\end{array}$ & $\begin{array}{r}2,9 \\
45,7 \\
40,0 \\
11,4 \\
\end{array}$ & $1,7 \pm 0,88$ \\
\hline$J o b$ & $\begin{array}{l}\text { Public Sector } \\
\text { Private Sector }\end{array}$ & $\begin{array}{c}0 \\
35\end{array}$ & $\begin{array}{c}0,0 \\
100,0\end{array}$ & $1,0 \pm 0,00 *$ \\
\hline Income Status & $\begin{array}{l}\text { 0-1500 Turkish Liras } \\
\text { 1501-3500 Turkish Liras }\end{array}$ & $\begin{array}{c}28 \\
7 \\
\end{array}$ & $\begin{array}{l}80,0 \\
20,0 \\
\end{array}$ & $1,2 \pm 0,40$ \\
\hline Living place & $\begin{array}{l}\text { Village } \\
\text { City } \\
\end{array}$ & $\begin{array}{c}1 \\
34 \\
\end{array}$ & $\begin{array}{c}2,9 \\
97,1\end{array}$ & $2,94 \pm 0,33$ \\
\hline Life Style & $\begin{array}{l}\text { With Family } \\
\text { Alone }\end{array}$ & $\begin{array}{c}32 \\
3 \\
\end{array}$ & $\begin{array}{c}91,4 \\
8,6 \\
\end{array}$ & $2,82 \pm 0,56$ \\
\hline Family Integrity & $\begin{array}{l}\text { Mother/Father in Life } \\
\text { Mother in Life } \\
\text { Father in Life } \\
\text { Mother/Father Dead }\end{array}$ & $\begin{array}{c}17 \\
6 \\
5 \\
7 \\
\end{array}$ & $\begin{array}{l}48,6 \\
17,1 \\
14,3 \\
20,0 \\
\end{array}$ & $2,05 \pm 1,21$ \\
\hline Disease Duration & $\begin{array}{l}1-7 \text { year } \\
8-15 \text { year }\end{array}$ & $\begin{array}{l}21 \\
14 \\
\end{array}$ & $\begin{array}{l}60,0 \\
40,0 \\
\end{array}$ & $6,74 \pm 3,55$ \\
\hline Forensic case & $\begin{array}{l}\text { Yes } \\
\text { No }\end{array}$ & $\begin{array}{c}2 \\
33 \\
\end{array}$ & $\begin{array}{c}5,2 \\
94,3 \\
\end{array}$ & $1,94 \pm 0,23$ \\
\hline TOTAL & & 35 & 100,0 & \\
\hline
\end{tabular}

$* \mathrm{p}<0.05$

According to the sectors that participants work, there is no significant difference between study groups $(\mathrm{p}<0.05)$.

Table II. Certain Anthropometric Characteristics of Participants and Sport Relation Distribution

\begin{tabular}{l|l|c|c|c}
\hline Variables & & $\boldsymbol{n}$ & $\boldsymbol{\%}$ & $\bar{x} \pm \mathrm{sd}$ \\
\hline \multirow{3}{*}{ Weight $(\mathrm{kg})$} & $55-64 \mathrm{~kg}$ & 5 & 14,3 & \\
& $65-74 \mathrm{~kg}$ & 14 & 37,1 & $72,28 \pm 6,98$ \\
& $75-84 \mathrm{~kg}$ & 15 & 40,0 & \\
\hline \multirow{2}{*}{ Length $(\mathrm{cm})$} & 85 and above & 1 & 8,6 & \\
\hline \multirow{3}{*}{ BMI $\left(\mathrm{kg} / \mathrm{cm}^{2}\right)$} & $160-174 \mathrm{~cm}$ & 24 & 68,6 & $171,7 \pm 6,81$ \\
& $175-186 \mathrm{~cm}$ & 11 & 31,4 & \\
& 18,5 and below (weak) & 0 & 0,0 & \\
\multirow{2}{*}{ Participation in sport } & $18.5-24,9$ (normal weight) & 23 & 65,7 & $24,4 \pm 1,78$ \\
& $25-29,9$ (overweight) & 12 & 34,3 & \\
\hline \multirow{2}{*}{ Sport branch } & $30-39,9$ (obese) & 0 & 0,0 & \\
& Yes & 30 & 85,7 & \\
& No & 7 & $14,14 \pm 0,35$ \\
\hline Total & Football & 8 & 20,0 & \\
\end{tabular}


$* \mathrm{p}<0.05, \mathrm{BMI}=$ Body Mass Index

Body weights of the participant were measured as $72.28 \pm 6,9 \mathrm{~kg}$, their lengths were measured as $171.7 \pm 6.81 \mathrm{~cm}$ and their BMIs were measured as $24.4 \pm 1,78 \mathrm{~kg} / \mathrm{m}^{2}$ in the research. It was figured out in this research that $85.7 \%$ ( $\mathrm{n}=30$ ) of the participants joins the exercise activities and $54.3 \%(n=19)$ of the participants does light brisk walking as physical activity.

Table III. IPAQ (International Physical Activity Survey) Results Distribution of Participants

\begin{tabular}{|c|c|c|c|c|c|}
\hline \multicolumn{2}{|c|}{ Physical Activities } & & $n$ & $\%$ & $\bar{x} \pm \mathrm{sd}$ \\
\hline \multirow{7}{*}{ Vigorous } & \multirow{4}{*}{ Week/day } & 1 days per week & 5 & 14,3 & \\
\hline & & 2 days per week & 8 & 22,9 & \\
\hline & & 3 days per week & 3 & 8,6 & $5,20 \pm 3,13$ \\
\hline & & $\mathrm{He} / \mathrm{she}$ did not & 19 & 54,3 & \\
\hline & \multirow{3}{*}{ Day/min. } & $15-20$ minutes per day & 7 & 20,0 & \\
\hline & & At least 15 minutes per day & 9 & 25,7 & $5,34 \pm 0,80$ \\
\hline & & Not sure & 19 & 54,3 & \\
\hline \multirow{12}{*}{ Moderate } & \multirow{6}{*}{ Week/day } & 1 days per week & 2 & 5,7 & \\
\hline & & 2 days per week & 10 & 28,6 & \\
\hline & & 3 days per week & 12 & 34,3 & \\
\hline & & 4 days per week & 8 & 22,9 & $3,17 \pm 1,52$ \\
\hline & & 5 days per week & 1 & 2,9 & \\
\hline & & $\mathrm{He} / \mathrm{she}$ did not & 2 & 5,7 & \\
\hline & \multirow{6}{*}{ Day/min. } & 1 hours per day & 3 & 8,6 & \\
\hline & & 45 minutes per day & 7 & 20,0 & \\
\hline & & 30 minutes per day & 16 & 45,7 & $3,02 \pm 1,17$ \\
\hline & & $15-20$ minutes per day & 6 & 17,1 & \\
\hline & & At least 15 minutes per day & 1 & 2,9 & \\
\hline & & Not sure & 2 & 5,7 & \\
\hline \multirow{11}{*}{ Walking } & \multirow{7}{*}{ Week/day } & 1 days per week & & & \\
\hline & & 2 days per week & 1 & 2,9 & \\
\hline & & 3 days per week & 6 & 17,1 & \\
\hline & & 4 days per week & 9 & 25,7 & $4,80 \pm 1,47$ \\
\hline & & 5 days per week & 10 & 28,6 & \\
\hline & & 6 days per week & 1 & 2,9 & \\
\hline & & 7 days per week & 8 & 22,9 & \\
\hline & \multirow{4}{*}{ Day/min } & 1 hours per day & 24 & 68,6 & \\
\hline & & 45 minutes per day & 6 & 17,1 & $1,48 \pm 0,81$ \\
\hline & & 30 minutes per day & 4 & 11,4 & \\
\hline & & $15-20$ minutes per day & 1 & 2,9 & \\
\hline \multirow{6}{*}{ Sitting } & \multirow{6}{*}{ Day/hour } & 3 hours per day & 1 & 2,9 & \\
\hline & & 4 hours per day & 5 & 14,3 & \\
\hline & & 5 hours per day & 9 & 25,7 & \\
\hline & & 6 hours per day & 7 & 20,0 & $3,77 \pm 1,23$ \\
\hline & & More than 6 hours per day & 12 & 34,3 & \\
\hline & & Not sure & 1 & 2,9 & \\
\hline Total & & & 35 & 100,0 & \\
\hline
\end{tabular}

$* \mathrm{p}<0.05$

It is established in the research that $54.3 \%$ of the participants doesn't join the physical activity, $34.3 \%$ of participants joins medium level activities for 30 minutes three times in a week, 28.6\% of them walks them for 1 hour 4 or 5 times in a week and their daily average sport duration is more than 6 hours $(34.3 \%)$.

Table IV. Distribution of Points for Beck's Depression Scale and STAI FORM TX-I-II Scale

\begin{tabular}{l|c|c}
\hline Point Types & t & p \\
\hline BDE &, 580 &, 566 \\
\hline STAI- TX-I (State Anxiety) & 1,293 &, 205 \\
\hline STAI-TX-II (Trait Anxiety) & $-2,632$ &, $013^{*}$ \\
\hline$* \mathrm{p}<0.05$ & &
\end{tabular}

It has been figured out that $14.3 \%(n=5)$ of patients has bland depression and $85.7 \%(n=30)$ of patients has major depression and all of the participants have high anxiety levels. While there is no significance in State Anxiety levels of participants, there are significant differences among Trait Anxiety levels. 
Table V. Evaluation of Genes with Psychological Evaluations

\begin{tabular}{l|c|c|c|c}
\hline Genes & $\overline{\mathbf{x}}$ & $\mathbf{S d}$ & $\mathbf{T}$ & $\mathbf{p}$ \\
\hline MAO-BDE & $-2,63$ &, 73 & $-21,27$ &, $000^{*}$ \\
\hline COMT-BAE & $-2,23$ &, 77 & $-17,11$ &, $000^{*}$ \\
\hline TH-BUE & $-2,86$ &, 43 & $-39,31$ &, $000^{*}$ \\
\hline SCL6A4-State Anxiety & $-49,94$ & 6,49 & $-45,53$ &, $000^{*}$ \\
\hline SCL6A4-Trait Anxiety & $-51,43$ & 5,66 & $-53,72$ &, $000^{*}$ \\
\hline
\end{tabular}

$* \mathrm{p}<0.05$

In accordance with the MAO (monoamineoxydase) genotype of mutant recurring numbers, an important significance which may be effective on depression observation related to enzyme activity changes has been determined (Table 5). Besides, an important increase in anxiety level with homozygote mutant genotype in COMT enzyme which is controlled by COMT (catechol-o-methyletransferase) has been determined. On the other hand, it may be mentioned that a relevant relation which can be trigger hopelessness table of homozygote mutant genotype related to tyrosine hydroxylase synthesis that is an important step for synthesis of hormones in catecholamine group may be observed. In addition, it has been figured out that relevance with SLC6A4 which is effective in the synthesis of serotonin hormone with related carrier protein, may be observed in the increase of risk in homozygote mutant type anxiety prevalence.

\section{Discussion}

Nowadays, the studies which contain genetic parameters of physical activity methods with psychological tests are attracting attention for schizophrenia and bipolar disorders' treatment in addition to the pharmacotherapy when medication doesn't meet demands. There are certain limited researches that show the positive effects of the regular physical exercise activities on the certain symptoms of psychiatric ailments in the literature and it was reported that physical exercise applications contribute to decrease symptoms and inflammation in psychiatric patients (Fariz 2005).

The demographical factors and physical activity levels of schizophrenia and bipolar patients were searched in this research and as the distribution of gender evaluated, it has been figured out that $68.6 \%(n=24)$ of the patients is male and their ages are between 26 and 41 and it has seen that their age average varies as $35,05 \pm 10,4$. When physical activity participation status was evaluated it has also been confirmed that $85.7 \%(\mathrm{n}=30)$ of the participants do physical activities and $54.3 \%(\mathrm{n}=19)$ of the participants do light brisk walking.

Stubbs et al. (2018) have presented certain proofs that shows, the patients who is at 30's and 40's ages and who suffers from mental diseases reflect certain cardiovascular symptoms and that physical activity play an important role in decreasing these symptoms and in improving physical health.

In addition, it is reported that prevalence of the schizophrenia according to gender is equal all over the world. It is also reported that schizophrenia is occurred before the age of 10 and after the age of 45 rarely but, it is also assumed that the occurrence age of the disease in male patients for male patients is $15-25$ and in female patients is $25-35$, assuming that the occurrence of the disease is at the earlier age in male patients in comparison to female patients (Sadock et al., 2009).

When distribution related to marital status and educational background of the patients were analyzed, it has been figured out that $74.3 \%$ of the patients is single $(n=26)$ and $45.7 \%$ of them was graduated from primary school $(n=16)$. When professional sectors of the patients were searched, no significant statistical difference has been determined $(0.00<0.05)$. It has seen that patients don't work difficult works that force their cognitive functions but their professionals vary from cobbler to vehicle mechanic, from hairdresser to textile employee and tailor. These types of professional also cause less stress so these professions don't play a trigger role in their diseases. Sadock et al. (2009) have stated in one of their studies that the frequency of schizophrenia is about 2 million in the world for each year and the prevalence risk of schizophrenia is higher than lower socio-economic conditions. The most frequent marital status that schizophrenia is emanated is single status. Besides, it is reported that the frequency of schizophrenia according to gender is equal to each other. It is also reported that schizophrenia is rarely seen at the ages before ten years and after forty-five years but the it has about 15-25 age at disease onset for male patients and it has about 25-35 age at the disease onset for female patients and it is stated that schizophrenia has earlier disease onset for male patients in comparison with female patients (Karakus et al., 2017). İt can be claimed that the prevalence of the schizophrenia differs from one country to another according to certain studies but there has still no study which shows the rate of prevalence according to genetic characteristics yet (Karakus et al., 2017).

In accordance with the physical activity level of participant individuals with schizophrenia and bipolar diagnosis, it has been figured out that $54.3 \%$ of the participant don't take part in physical activities, that $34.3 \%$ of them do medium sports activities three times in a week for 30 minutes and that $28.6 \%$ and $25.7 \%$ of the participants walks 4 or 5 times in a week for 1 hour. It has been confirmed that $34.3 \%$ of the individuals spends their 6 hour by sitting. The patients with schizophrenia and bipolar diagnosis do generally light and medium level sportive activities whereas they are hard put to do vicious sportive activities. Vancampfort et al. (2013) has found in their study that there is a low relationship between 
insufficient physical activity participation and their self-sufficiency, comorbidity, educational background and social isolation in schizophrenia and bipolar patients. According to these outcomes, it was detected that the body mass index of the bipolar disorder individuals who have lower physical activity participation tend to increase.

The average body weight is $72.28 \pm 6.9$, average length is $171.7 \pm 6.81$ and BMI is $24.4 \pm 1.78 \mathrm{~kg} / \mathrm{m}^{2}$ in this research. While the obesity prevalence is wide in patients with bipolar disorders, this circumstance may be related to increasing medical morbidity and bad psychiatric outcomes. The variables that may interact with obesity prevalence and prevention of obesity in bipolar disorders include; genetic factors, neurotransmitter abnormalities, atypical depression, eating behaviors, pharmacotherapy, age, gender, socio-economic status and physical hypokinesia. In accordance with the study of Wildes et al. (2006); the obesity factors in bipolar disorders were searched and it was concluded that biological, psychological and socio-demographic variables, sedentary lifestyle and eating behaviors disorders may lead to obesity in this population. Patients with bipolar disorders should be informed about increasing physical activity and decreasing uncontrolled and excessive eating behaviors and studies which expand awareness are needed.

According to outcomes of a study which has studied about effects of regular physical exercise programs on psychological diseases, it is reported that these programs are subsidiary elements for the treatments of these diseases and it is also emphasized that this kind of studies should be remarked (Tkachuk \& Martin 1999). Acil et al. (2008) have conducted a study which examines effects of physical exercises on life quality of schizophrenia patients, according to results of this study it is reposted that, physical exercise programs decrease psychiatric symptoms of schizophrenia patients and that these programs are also effective for increasing the life quality of these patients.

Melo et al. (2016) have concluded in their study that bipolar patients who join the physical exercise activities have less depressive symptoms and these activities also increase their life qualities and their functionalities. Besides they also stated the relationship between exercises done and mania. Exercise is generally associated with health precautions including depressive symptoms, functionality and life quality. Researches with randomized studies are needed to make clear the role of physical activities in bipolar patients.

Loh et al. (2016) have conducted a study with schizophrenia patients who make physical exercises for 3 months and it is reported that their functionality points increase and their negative symptoms decrease, Beebe et al. (2013) have conducted a study with schizophrenia patients who make physical exercises for 4 months and they figure out that positive and negative symptoms measurements decrease severely in schizophrenia patients with exercise, Cassilhas et al (2015) have conducted a study with schizophrenia patients who make physical exercises for 5 months and they compared the patients with physical exercise and patients without physical exercise and they concluded that positive-negative symptoms and depression levels are decreased with physical exercises in comparison to patients without exercise and finally Ho et al. (2016) have conducted a study with schizophrenia patients who do "tai-chi exercise" for 6 months and they figured out that positive symptoms increase and negative symptoms decrease and there is no significance in patients without physical exercise and besides Dodd et al. (2011) have conducted a study with psychological patients who make physical exercises for 7 months and they reported a decrease in negative symptom measurements and increase in positive symptom measurements with physical exercise.

Vancampfort \& Goldstein (2018) have examined physical health status of BD patients and they stated that the proof showing the positive effects of physical exercise activities on the treatment of $\mathrm{BD}$, that physical exercise activities should be included in routine health applications and that they hope sustainable health policy may be established when these exercises are included (Vancampfort \& Goldstein 2018). These sorts of ameliorations become more of an issue to decrease different mortality and morbidity rates and to increase life quality related to psychological and physical health.

The outcomes of the studies in which chronic schizophrenia patients participate to physical exercises show that patients' moods get better mentally, while they become more responsive psychologically and socially, an increase in their adaptation to medical treatment is observed. Health should be defined not only physically it should also be defined psychologically (Lök \& Lök 2016). For these reasons, it is important to involve regular, systematic and sustainable exercise plans into treatment of psychological patients.

Stubbs et al. (2018) has presented clear proofs in one of their studies that shows physical activity plays a central role for decreasing burden of psychological health symptoms of bipolar depression and schizophrenia patients According to the experts who claims that exercise should be included standard medical treatment and psychotherapy additionally to treat patients better, and structured physical activity program should contain doing exercise two and three times in a week so that bipolar depression and schizophrenia symptoms may be decreased. In accordance with yielded outcomes of the research, European Psychiatry Association (EPA) proposes that exercise should be done in addition to medical treatment of psychological diseases and they published a guideline to encourage this proposition. Scientists agreed on EPA instructions published by European Psychiatry Association and they have also suggested that structural exercise program should be included to standard medical treatment and psychotherapy. Stubbs \& Rosenbaum (2018) have 
concluded in one of their studies that exercising decreases psychological disorder symptoms effectively and improve their cognitive functions and that exercising also ameliorate cardio-vascular health of schizophrenia patients and spectrum disorders of schizophrenia and cognitive and cardio-respiratory health may be improved with medium aerobic exercise and that exercising also decreases depression and schizophrenia symptoms. The outcomes of the study support the combination of aerobic and resistant exercise in the treatment of spectrum disorders of schizophrenia and major depression patient. EPA instructions have also been supported by International Organization of Physical Therapist of Mental Health (IOPTMH). Nowadays, the studies which search the effect of physical exercise on psychological health have been increased. In addition, there is a significant relation between physical exercise and decrease of depression symptoms was observed in clinical research and physical exercises are effective on many psychological diseases including depression initially (Karatosun 2011).

The relationship between certain gene variations and psychological factors with physical activity levels in schizophrenia and bipolar patients is reviewed with several dimensions in this research. In consideration of the outcomes of research it may be stated that metabolite accumulation can be decreased which is caused by MAO (monoamineoxydase) genotype mutant recurring number related to enzyme activity change relatively to dopamine and adrenaline hormone collapse decrease. Said statement may be effective on depression observation. Morisihima et al. (2006) have reported in their research that MAO-A activity influences tiredness and performance in response to increasing serotonin production during long-term exercise. In addition, the activity discrepancy that may be improved by homozygote mutant genotype in COMT enzyme which is controlled by COMT (catechol-o-methyletransferase) may increase anxiety intensity based on possible adrenaline, noradrenaline and dopamine hormone accumulations in conjunction with dopaminergic system. Bobb et al. (2006) has determined in their research that functional polymorphism in COMT gene may lead to change in COMT enzyme activity that is responsible to regulate dopamine degradation so that it cause to occurrence of schizophrenia, bipolar disorders, obsessive-compulsive disorders, migraine; aggressive and anti-social behaviors occurrence.

On the other hand, it has been observed in our research that, possible insufficient catecholamine hormone in individuals who have from said TH gene and related genotype homozygote mutant type that are effective on tyrosine hydroxylase synthesis which is one of the important step on the hormone synthesis of catecholamine may trigger hopelessness table of individuals especially by insufficient dopamine.

In this research it has been reported that a special positive relationship between TH gene that plays a role in pathophysiology of psychiatric disorders and mood disorders (Allessandro et al., 2002). XU et al. (2007) have analyzed effects of long-term and short-term stress on TH activity and they have reported that long-term stress increases TH activity by triggering $\mathrm{TH}$ protein production in adrenal medulla. Besides, it may also be reported that homozygote mutant type of SLC6A4 gene that is effective on the synthesis of carrier protein related serotonin hormone may lead to risk in occurrence of anxiety which is related to deficiency of cell and tissue group transfer. Guhathakurta et al (2006) has stated in their research that it is neurotransmitter that has an important role in serotonin center and peripheral nervous system and $\mathrm{S}$ allele may lead to tendency in psychiatric disorders and stressful life may be related to this circumstance. They have also been figured out that change in transcription speed of SLC6A4 gene may be related to endurance performance (Heils et al., 1996). In addiction these data, it has been also stated by using pharmacological approach that serotonin manipulation has an important effect on physical performance and central tiredness, perception and motivation since it is related to psychiatric disorders including mood disorders like 5-HTT activity of brain, impulsive behavior, depression and anxiety (Gee 2010).

The fundamental aim of the researches conducted is to solve dilemma of schizophrenia and bipolar patients between life quality and recovery and to elute certain factors that influence its relation with sportive performance. Physical exercise results that have been obtained from patients with schizophrenia and bipolar diagnosis in different times and at different types also support our research outcomes. In accordance with our research outcomes we think that genetic variations, field tests and psychological tests may influence treatment durations and medical regimens of the patients positively.

\section{References}

Acil, A. A., Doğan, S., \& Doğan, O. (2008). The effects of physical exercises to mental state and quality of life in patients with schizophrenia. Journal of Psychiatric and Mental Health Nursing, 15(10),

808-815. https://doi.org/10.1111/j.1365-2850.2008.01317.x

Anding, K., Bär, T., Trojniak-Hennig, J., Kuchinke, S., Krause, R., \& Rost, J. M. (2015). A structured exercise programme during haemodialysis for patients with chronic kidney disease: clinical benefits and long-term adherence. BMJ Open. 5(8), e008709. https://doi.org/10.1136/bmjopen-2015-008709

Atmaca, G. D., \& Durat, G. (2016). Şizofreni hastalarında intihar ve depresyon. Düzce Üniversitesi Sağllk Bilimleri Enstitüsü Dergisi, 6(1), 51-55. 
Avşar, F. (2007). Doğrulayıcı faktör analizi ve beck depresyon envanteri üzerine bir uygulama. Yayımlanmamış Yüksek Lisans Tezi. Yıldız Teknik Üniversitesi Fen Bilimleri Enstitüsü.

Baskak, B., Atbaşoğlu, E. C., \& Saka, M. C. (2009). Şizofreni etiyolojisinde psiko-sosyal etmenlerin rolü: Antipsikiyatriden gen çevre etkileşimine. Nöropsikiyatri Arşivi, 46(5), 1-9.

Beck, A. T., Ward, C. H., Mendelson, M., Afocfc J., \& Erbaugh, J. (1961). An inventory far measuring depression. Arcieves of General Psychtatry, 1(4), 561-571. https://doi.org/10.1001/archpsyc.1961.01710120031004

Beck, A. T., Weissman, A., Lester, D., \& Trexler, L. (1974). The measurement of pessimism: the hopelessness scale. $J$ Consult Clin Psychol; 42, 861-865. https://doi.org/10.1037/h0037562

Beck, A.T., Epstein, N., Brown, G., \& Steer, R. A. (1988). An inventory for measuring clinical anxiety: Psychometric properties. Journal of Consulting and Clinical Psychology, 56(6), 893-897. https://doi.org/10.1037/0022-006X.56.6.893

Beebe, L. H., Smith, K. D., Roman, M. W., Burk, R. C., McIntyre, K., \& Dessieux, O. L. (2013). A pilot study describing physical activity in persons with schizophrenia spectrum disorders (SSDS) after an exercise program. Issues Ment Health Nurs., 34, 214-219. https://doi.org/10.3109/01612840.2012.746411

Bobb, A. J., Castellanos, F. X., Addington, A. M., \& Rapoport, J. L. (2006). Molecular genetic studies of ADHD:1991 to 2004. Am J Med Genet B Neuropsychiatr Genetic, 141, 551-565.

Buchanan, R. W., \& Carpenter, W. T. (2005). Kaplan and Sadock's Comprehensive Textbook of Psychiatry. Chapter Concept of Schizophrenia. Lippincott Williams and Wilkins. Philadelphia. B. J. Sadock and V. A. Sadock (Eds.)

Cassilhas, R. C., Attux, C., Cordeiro, Q., Gadelha, A. L., Telles, B. A., \& Bressan, R. A. (2015). A 20-week program of resistance or concurrent exercise improves symptoms of schizophrenia: results of a blind, randomized controlled trial. RevBrasPsiquiatr, 37, 271-279. https://doi.org/10.1590/1516-4446-2014-1595

Collier, D. A., Stöber, G., Li, T., Heils, A., Catalano, M., \& Di Bella, D. (1996). A novel functional polymorphism within the promotor of the serotonin transporter gene: possible role in susceptibility to affective disorders. Mol Psychiatry, 1, 453-460.

Dodd, K. J., Duffy, S., Stewart, J. A., Impey, J., \& Taylor, N. (2011). A small group aerobic exercise programme that reduces body weight is feasible in adults with severe chronic schizophrenia: a pilot study. Disabil Rehabil, 33, 1222-1229. https://doi.org/10.3109/09638288.2010.526162

Epstein, D. (2013). The Sports Gene. Inside the science of extraordinary athlethic performance. The gene-Free Model of Expertise. Penguin Group. New York.

Ertuğrul, A. (2005). Şizofreni Etiyolojisi. Turkiye Klinikleri, Journal Of Internal Medical Sciences, 1(12), 6-14.

Fariz, B. (2015). Psikiyatrik hastalıklar ve egzersiz. Derince Eğitim ve Araştırma Hastanesi Spor Hekimliği Birimi, 4(50), 131-138.

Faulkner, G., Cohn, T., \& Remington, G. (2006). Validation of a physical activity assessment tool for individuals with schizophrenia. Schizophrenia Research, 82(2-3), 225-231. https://doi.org/10.1016/j.schres.2005.10.020

Gee, C. J. (2010). How does sport psychology actually improve athletic performance? A framework to faciliate athletes and coaches' understanding. Behav.Modif, 34, 386-402. https://doi.org/10.1177/0145445510383525

Guhathakurta, S., Ghosh, S., Sinha, S., Chatterjee, A., Ahmed, S., Chowdhury, S. R., Gangopadhyay, P. K., Ghosh, S., Singh, M., \& Usha, R. (2006). Serotonin transporter promoter variants: Analysis in Indian autistic and control population. Brain Res. 1092, 28-35. https://doi.org/10.1016/j.brainres.2006.03.078

Heils, A., Teufel, A., \& Petri, S. (1996). Allelic Variation of the Human Serotinin Transporter Gene Expression. $J$ Neurochem, 66(6), 2621-2624. https://doi.org/10.1046/j.1471-4159.1996.66062621.x

Ho, R. T., Fong, T. C., Wan, A. H., Au-Yeung, F. S., Wong, C. P., \& Ng, W. Y. (2016). A randomized controlled trial on the psychophysiological effects of physical exercise and Tai-chi in patients with chronic schizophrenia. SchizophrRes, 171, 42-49. https://doi.org/10.1016/j.schres.2016.01.038

Işı1k, E., \& Işık, U. (2008). Şizofreni. Güncel Klinik Psikiyatri. Asimetrik Paralel Yayıncıllk, Ankara: 81-115.

Karakuş, G., Kocal, Y., \& Sert, D. (2017). Şizofreni: Etiyoloji, klinik özellikler ve tedavi. Arşiv Kaynak Tarama Dergisi, 26(2), 251-267. https://doi.org/10.17827/aktd.303574

Karatosun, H. (2011). Fiziksel Aktivite ve Ruh Sağlığı. Süleyman Demirel Üniversitesi Yaşam Dergisi, 2(2), 09-13.

Köroğlu, E. (2013). Psikiyatri Başvuru El Kitabı. HYB Yayıncılık. 2. Baskı. Ankara, 
Loh, S. Y., Abdullah, A., Bakar, A. K. A., \& Jaafar, N. R. N. (2015). Structured walking and chronic institutionalized schizophrenia in mates: a pilot RCT study on quality of life. Glob J Health Sci., 8, 238-248.

Lök, S., \& Lök, N. (2016). Kronik psikiyatri hastalarına uygulanan fiziksel egsersiz programlarının etkinliği: Sistematik Derleme. Current Approaches in Psychiatry/ Psikiyatride Güncel Yaklaşımlar, 8(4). https://doi.org/10.18863/pgy.253440

Melo, M., Daher, E., Albuquerque, S., \& De Bruin, V. (2016). Exercise in bipolar patients: A systematic review. Journal of Affective Disorders. https://doi.org/10.1016/j.jad.2016.03.004

Morishima, M., Harada, N., Hara, S., Sano, A., Seno, H., Takahashi, A., Morita, Y., \& Nakaya, Y. (2006). Monoamine oxidase A activity and norepinephrine level in hippocampus determine hyperwheel running in SPORTS rats. Neuropsycho pharmacology, 31(12), 2627-2638. https://doi.org/10.1038/sj.npp.1301028

Öner, N., \& Le Compte, A. (1983) Durumluk-sürekli kaygı envanteri el kitabı, Boğaziçi Üniversitesi Yayınları. İstanbul.

Sabol, S. Z., Hu, S., \& Hamer, D. (1998). A functional polymorphism in the monoamine oxidase A gene promoter. Hum.Genetic, 103, 273-279. https://doi.org/10.1007/s004390050816

Sadock, B. J., \& Sadock, V. (2009). Study guide and self-examination review in psychiatry, eighth edition. Philadelphia: Lippincott Williams Wilkins.

Sağlam, M, Arıkan, H., Savcı, S., İnal, İ. D., Boşnakgülü, M., \& Karabulut, E. (2010). International physical activity questionnaire: reliability and validity of the Turkish version. Percept Mot Skills; 111(1), 278-84.

Seber, G., Dilbaz, N., Kaptanoğlu, C., \& Tekin, D. (1993). Umutsuzluk ölçeği: geçerlilik ve güvenirliği. Kriz Dergisi, 1, 139-142.

Serretti, A., Macciardi, F., Verga, M., Cusin, C., Pedrini, S., \& Smeraldi, E. (2002). Tyrosine hydroxylase gene associated with depressive symptomatology in mood disorder. https://doi.org/10.1002/(SICI)1096-8628(19980328)81:2<127::AID-AJMG1>3.0.CO;2-T

Soygür, H., Alptekin, K., Atbaşoğlu, E. C., \& Herken, H. (2007). Şizofreni ve diğer psikotik bozukluklar. Türkiye Psikiyatri Derneği Yayınları, 500, 1. Baskı. Ankara,

Spielberger, C. D., Gorsuch, R. L., \& Lushene, R. E. (1970) Manual for state-trait anxiety inventory: Consulting Psychologist.

Stubbs, B., \& Rosenbaum, S. (2018). Exercise-based interventions for mental illness. Physical Activity as Part of Clinical Treatment. 1st Edition.

Stubbs, B., Vancampfort, D., Hallgren, M., Firthe, J., Veronese, N., Solmi, M., ... Kahl, K. G. (2018). EPA guidance on physical activity as a treatment for severe mental illness: a meta-review of the evidence and Position Statement from the European Psychiatric Association (EPA), supported by the International Organization of Physical Therapists in Mental Health (IOPTMH) European Psychiatry. pp. 124-144. https://doi.org/10.1016/j.eurpsy.2018.07.004

Stubbs, B., Vancampfort, D., Rosenbaum, S., Ward, P. B., Richards, J., Soundy, A., .. Vancampfort, S. (2016). Dropout from exercise randomized controlled trials among people with depression: a meta-analysis and meta regression. Journal of Affective Disorder. 190, 457-466. https://doi.org/10.1016/j.jad.2015.10.019

Tkachuk, G. A., \& Martin, G. L. (1999). Exercise therapy for patients with psychiatric disorders: Researchand clinical implications. Professional Psychology: Research and Practice, 30(3), 275. https://doi.org/10.1037/0735-7028.30.3.275

Uğur, M. (2008). Duygudurum bozuklukları. ÏÜ Cerrahpaşa Tip Fakültesi Sürekli Tip Eğitimi Etkinlikleri Sempozyum Dizisi, 62, 59-84.

Ulusoy, M., Şahin, N., \& Erkmen, H. (1998). Turkish version of the beck anxiety inventory: Psychometric Properties. Journal of Cognitive Psychotherapy, 12, 163-172.

Vancampfort, D., \& Goldstein, B. I. (2018). Bipolar disorder and physical activity. Exercise-based interventions for mental illness. Physical Activity as Part of Clinical Treatment. Book; Chapter 3. pp. 53-63. https://doi.org/10.1016/B978-0-12-812605-9.00003-4

Vancampfort, D., Correll, C., Probst, M., Sienaert, P., Wyckaert, S., De Herdt, A., Knapen, J., De Wachter, D., \& De Hert, M. (2013). A review of physical activity correlates in patients with bipolar disorder. Journal of Affective Disorders. https://doi.org/10.1016/j.jad.2012.07.020

Wildes, J., Marcus, M., \& Fagiolini, A. (2006). Obesity in patients with bipolar disorder: A biopsychosocial-behavioral 
model. Journal of Clinical Psychiatry. 67(6), 904-915. https://doi.org/10.4088/JCP.v67n0607

Xu, L., Chen, X., Sun, B., Sterling, C., \& Tank, A.W. (2007). Evidence for regulation of tyrosine hydroxylase mRNA translation by stress in rat adrenal medulla, Brain Research, 1158, 1-10.

https://doi.org/10.1016/j.brainres.2007.04.080

Yeung, W. L., Wong, V. C., Chan, K.Y., Hui, J., Fung, C. W., Yau, E., ... Low, L. (2011). Expanding phenotype and clinical analysis of tyrosine hydroxylase deficiency. J Child Neurol. 179-187.

https://doi.org/10.1177/0883073810377014

\section{Copyrights}

Copyright for this article is retained by the author(s), with first publication rights granted to the journal.

This is an open-access article distributed under the terms and conditions of the Creative Commons Attribution license which permits unrestricted use, distribution, and reproduction in any medium, provided the original work is properly cited. 